\title{
THE EFFECT OF LIFESTYLE ON THE DEMAND FOR ALTERNATIVE TOURISM
}

\author{
Asst. Prof. Fatih PEKTAŞ \\ Aksaray University, Güzelyurt Vocational School, Aksaray, Turkey, (fpektas@aksaray.edu.tr)
}

\begin{abstract}
Tourism demand was strongly affected by cultural, social, personal, and psychological characteristics. Lifestyle is one of the personal and psychographic characteristics and this study was designed to investigate whether life style affects the demand for alternative tourism. This study was conducted in Aksaray, Turkey and study data were gathered from 402 participants, determined through convenience sampling method, via a questionnaire. Results of the multiple regression analyses demonstrated the effect of lifestyle on the demand for alternative tourism. Thus, this study revealed the importance of alternative tourism as a tourism product diversification tool according to target markets' lifestyle.
\end{abstract}

Keywords: Lifestyle, Alternative Tourism, Market Segmentation, Tourism Diversification.

\section{YAŞAM TARZININ ALTERNATIF TURIZM TALEBİ ÜZERINE ETKİII}

\begin{abstract}
ÖZET
Turizm talebi güçlü bir şekilde kültürel, sosyal, kişisel ve psikolojik özelliklerden etkilenmektedir. Bu araştırma kişisel ve psikolojik özelliklerden olan yaşam tarzının alternatif turizme olan talebi etkileyip etkilemediğini araştırmak üzere kurgulanmıştır. Anket formunun ve kolayda örneklemin kullanıldı ̆̆ bu araştırma, 402 katılımcı ile Aksaray ili, Türkiye'de gerçekleştirilmiştir. Çoklu regresyon analizi sonuçları yaşam tarzının alternatif turizme olan talebi etkilediğini göstermektedir. Buradan hareketle, bu çalışma hedef pazarın yaşam tarzına göre alternatif turizmin bir turizm çeşitlendirme aracı olarak kullanılabilmesinin önemini ortaya koymaktadır.
\end{abstract}

Anahtar Kelimeler: Yaşam Tarzl, Alternatif Turizm, Pazar Bölümlendirme, Turizm Çeşitlendirme. 


\section{Introduction}

Tourism is an important industry in the economy of countries and statistical indicators show the power of tourism, too. Receipts from international visitor spending on accommodation, food and drink, entertainment, shopping and other services and goods

International tourism expenditures reached an estimated US\$ 1245 billion in 2014, and international tourist arrivals (overnight visitors) hit a record 1133 million worldwide in 2014 (UNWTO, 2015). Therefore, tourism has a positive impact on the economy of a country through increased domestic income and foreign exchange earnings, economic multiplier effect, increased employment, improved infrastructure and living standards (Lertcharoenchoke, 1999; Dale, 2010). Thus, destinations which have tourism potential compete fiercely in order to gain more of the total tourism expenditures. These efforts require a focus on supply and demand side of tourism. Alternative tourism may be considered as a tourism product diversification tool and lifestyle could be one of the major factors in consumer decision making process. Determining the effect of lifestyle on the demand for alternative tourism will give the tourism marketing professionals the opportunity to use it in their marketing efforts. Furthermore, it will make alternative tourism a real strong rival to mass tourism, resulting in more sustainability and protection of tourism resources.

The purpose of this research is to determine the effect of lifestyle on the demand for alternative tourism. All tourism types except mass tourism could be categorized in alternative tourism. The main aims of alternative tourism are both to constitute an alternative to mass tourism and to provide another opportunity for destinations to diversify their tourism products. By diversifying tourism products, destinations supply different tourism products to the target market. Determining the effect of lifestyle on the demand for alternative tourism types might provide a significant contribution to the success of destination marketing efforts. Thus, destination marketing professionals may diversify their tourism products according to lifestyles of target markets.

\section{Literature Review}

\subsection{Alternative Tourism}

The latter half of the twentieth century has been marked with amazing changes in technology, transportation, and communication and these changes have triggered the development of a number of new industries. Tourism is one of these industries and it has quietly emerged to become an important force in many societies and economies in various parts of the world (Smith \& Eadington, 1992). Besides the positive impacts of tourism, it is possible to mention the negative effects such as causing ecocide by exceeding the carrying capacity in tourism. Therefore alternative tourism could be taken into consideration to reduce the concequences of mass tourism.

Alternative tourism, along with heritage and sustainable development, attracted greater attention in the 1980s (Butler, 1990) and it still is a topic of interest. The concept of alternative tourism covers all types of tourist activities except mass tourism. Alternative tourism raised more criticism towards mass tourism due to the problems it has triggered. Thus, alternative 
tourism has been considered as a hope to provide sustainability for natural, social, and community values. Main concept of alternative tourism is that alternative forms of tourism will have less negative effects on destinations without decreasing the positive economic effect (Tezcan, 2004). In addition, alternative tourism is a tool for tourism product diversification. The changes in the consumer demand resulted in more tourism product diversification efforts. These efforts emerged alternative tourism types as an alternative to the conventional tourism product, namely, sea, sand, and sun (K1lic \& Kurnaz, 2010). Thus, from the supply point of view, alternative tourism provides two major opportunities;

- Protection of nature, culture.

- Diversification of tourism products.

Gartner (1996) compared mass tourism and alternative tourism according to general features of these tourism types and tourist behaviors. It is obvious that alternative tourism is more nature and people oriented than mass tourism. Table 1 demonstrates the comparison.

Table 1: Comparison of Mass Tourism and Alternative Tourism

\begin{tabular}{|c|c|c|}
\hline & MASS TOURISM & ALTERNATIVE TOURISM \\
\hline \multirow{12}{*}{$\begin{array}{l}\text { General } \\
\text { Features }\end{array}$} & Rapid Development & Slow Development \\
\hline & Maximizes & Optimizes \\
\hline & $\begin{array}{l}\text { Socially, environmentally } \\
\text { inconsiderate, aggressive }\end{array}$ & $\begin{array}{l}\text { Socially, environmentally considerate, } \\
\text { cautions }\end{array}$ \\
\hline & Short Term & Long Term \\
\hline & Remote control & Local Control \\
\hline & Unstable & Stable \\
\hline & Price Consciousness & Value consciousness \\
\hline & Quantitative & Qualitative \\
\hline & Growth & Development \\
\hline & Peak holiday periods, seasonal & $\begin{array}{l}\text { Staggered holiday periods, no } \\
\text { necessarily seasonal }\end{array}$ \\
\hline & Capacity for high seasonal demand & Capacity for average seasonal demand \\
\hline & Tourism development everywhere & Development only in suitable places \\
\hline \multirow{4}{*}{$\begin{array}{l}\text { Tourist } \\
\text { Behaviors }\end{array}$} & Large Groups & Singles, families, small groups \\
\hline & Fixed program & Spontaneous Decisions \\
\hline & Tourists directed & Tourists decide \\
\hline & Comfortable and Passive & Demanding and active \\
\hline
\end{tabular}

Source: Gartner (1996). Tourism Development: Principles, Processes, and Policies. New York: Van Nostrand Reinhold. 
The activities classified as alternative tourism are various, but might be divided into certain categories as follows (Tezcan, 2004).

- Cultural and historical tourism

- Health tourism

- Conference- congress tourism

- Sports based tourism

- Nature/eco- tourism

- Entertainment tourism

\subsection{Lifestyle}

Because the consumer's decision is influenced strongly by cultural, social, personal, and psychological factors, marketing professionals take these factors into account. They also consider geographic, demographic, psychographic, and behavioral factors as major segmentation variables for consumer markets. Lifestyle is one of the important personal and psychographic factors. People from the same subculture, social class, and occupation may have quite different lifestyles. Lifestyle is defined as a person's pattern of living (Kotler \& Keller, 2012: 167).

There are various scales in marketing literature such as Activities, Interests and Opinions (AIO), Rokeach Value Survey (RVS), List of Value (LOV), Schwartz Value System (SVS), Research Institute on Social Change (RISC), Eurostyles of Centre de Communication Avance (CCA), Value and Lifestyles (VALS) that aim to measure personal values, attitudes and lifestyles (Solomon et al., 2006).

The most well-known and widely used consumer segmentation tool in the USA is VALS, which was developed at Stanford Research Institute (SRI) International by Arnold Mitchell in the 1970s and now officially applied by SRI Consulting Business Intelligence. VALS was developed on the theoretical basis of Maslow's hierarchy of needs and Riesman's theory of social character. Consumers in the USA were split into four main categories and nine subcategories. The categories were as follows; need driven (survivor, sustainer), outer directed (belonger, emulator, achiever), inner directed (i-am-me, experiential, socially conscious), and integrated (Lin, 2003; Michman et al., 2003; Khan, 2006).

VALS was updated in 1989 according to criticisms of the VALS model, as well as changing social values to enhance its ability to predict consumer behavior. The new model was called VALS II. USA citizens were segmented into eight groups: actualizers (innovators), fulfilleds (thinkers), achievers, experiencers, believers, strivers, makers, and strugglers (survivors) (Lin, 2003; Solomon et al., 2006; Peter \& Olson, 2010). According to US VALS framework, primary motivation and resources are two critical components to understand customer lifestyle. These components determine how a person acts in the marketplace as a customer. Primary motivations consist of ideals, achievement, and self-expression. Consumers who are driven by knowledge and principles are ideal oriented. Consumers who aim to emphasize their success with the products and services they buy are achievement oriented. Consumers who desire 
physical activity, variety, and risk are self-expression oriented. Characteristics such as age, income, education, energy, self-confidence, intellectualism, novelty seeking, innovativeness, impulsiveness, leadership, and vanity constitute resources (VALS, 2015). The components of VALS classification presented in Figure 1.

Figure 1: VALS II Segments

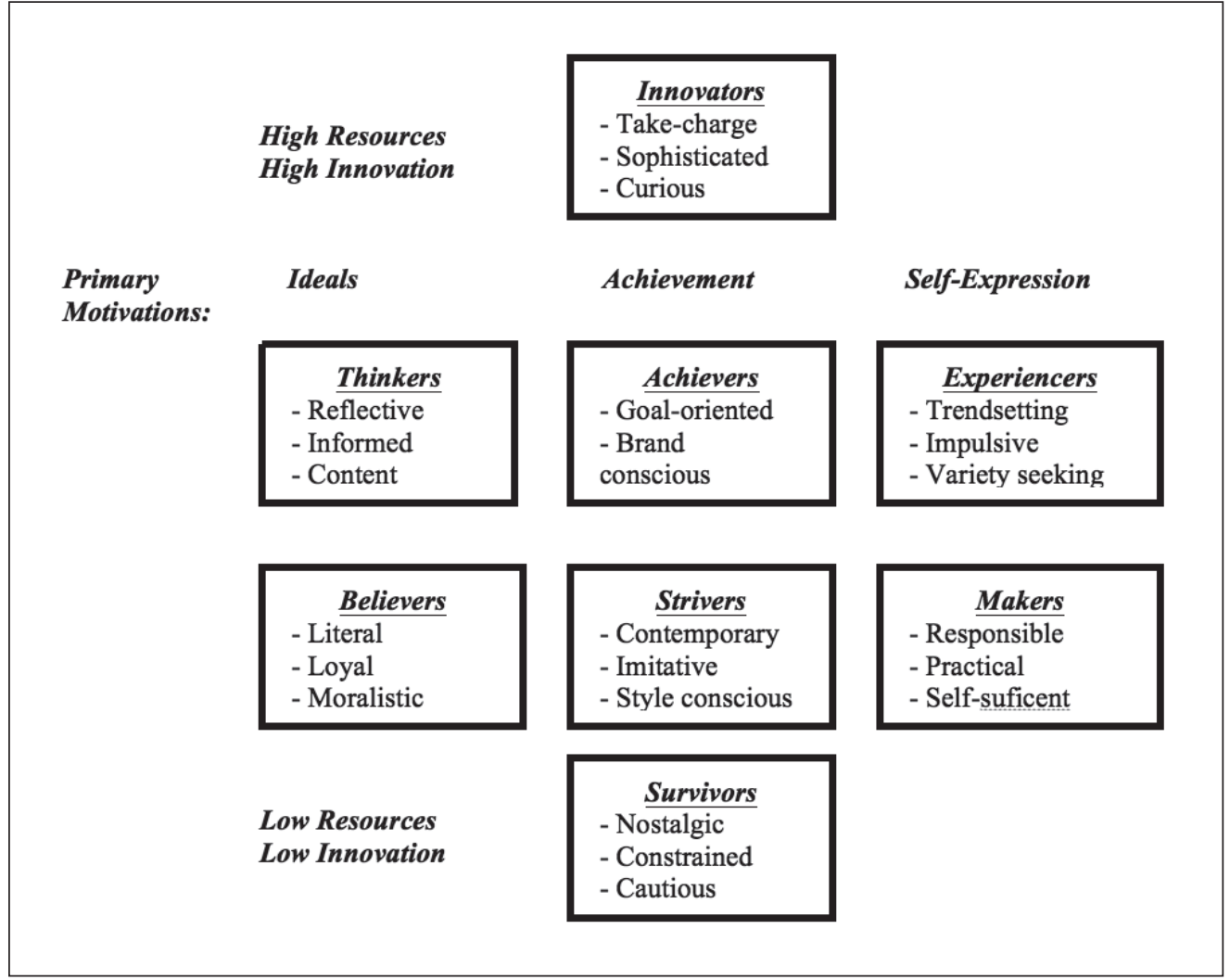

Source: Hoyer \& Maclnnis (2008). Consumer Behavior, 5th edition, South-Western, USA .Jersey.

The characteristic of VALS II segments are as follows (Deniz et. al., 2011; Kaya 2013; Y1ldırım \& Cengel, 2013):

Innovators (Actualizers): These people are researcher, sophisticated, successful and active take care of themselves and highly educated. They have abundant resources and exhibit all three primary motivation (ideals, achievement and self-expression) follow new ideas/ technology. These people are active customer and buy products of upper social classes. Image, power and statue are indicators of their personality. They have a wide range of hobbies and open the change. 
Thinkers (Fullfilleds): People who motivated by ideals. They are mature, relax and confident people who care responsibility and knowledge. Most of them have high education level and research before make a decision. They keen on current news and developing themselves. Even their incomes allow them many choices; they are conservative, practical customer. Functionality, longevity and price are important factors for them.

Achievers: People who motivated by the desire for achievement. They generally focus on their career, work environment and tend to control their life. They are conservative people and respectful to the current authority. They have enormous wants. Prestigious products and services are important for them to show their success. That is why they care image.

Experiencers: People who motivated by self-expression. They are young, enthusiastic, rebel and hokey consumer who look for excitement, extraordinary and innovative products. Their ideas and thrills are temporary and change time to time. Most of their activities are related with sports, entertainment and social activities and they spend their money mostly on clothes, readily available food, music and cinema.

Believers: Motivated by ideals like thinkers. Believers are conservative and traditional people who attached to their traditions. Families, religion, society and social rules are imported for them. They are religious people who spend their life close to their families. They have limited income. They prefer national and familiar products.

Strivers: Strivers are trendy and fun loving people who are motivated by achievement. They concern what other people think about them. They care been approved by others. They don't have enough money to meet their desire so money means success for them. They are active consumers because shopping is both a social activity and an opportunity to demonstrate to peers their ability to buy.

Makers: They are motivated by self-expression like experiencers. They express themselves such as building houses, raising children, fixing cars, doing models, doing handcrafts, growing vegetables. Makers are politically conservative and suspicious of new ideas and large institutions such as big business. They are respectful of government authority and they consume practical and functional products instead of luxury products.

Survivors (Strugglers): They are poor, low educated and unqualified people who don't have tight social links. They feel comfortable with the familiarity and take safety and security as a primary issue. They don't show a strong primary motivation and they are cautious customer. Strugglers are loyal to favorite brands, especially if they have an opportunity buy them at a discount.

\section{Research Methodology}

Questionnaire was conducted for this research in the city of Aksaray from March through April 2015. Aksaray is a city in the middle of Anatolia, Turkey with a population of 384,252 (Turkey in Statistics, 2015). Convenience sampling was used with 402 respondents. In order to measure lifestyle by VALS II, 35 questions were used (Lin, 2003). 
Tourism types except mass tourism were considered as alternative tourism activities so twenty alternative tourism items were developed on the basis of a review of the alternative tourism literature and were modified for this research. After removing the overlapping items and those which have factor loading less than .50 , the residual 12 items gathered under 3 factors. Five-point Likert scale was used in order to measure lifestyle and alternative tourism types. The survey instrument consisted of three parts. First part was comprised of lifestyle questions; second one was comprised of alternative tourism types; and third one was comprised of demographic features.

\section{Results}

The demographic profiles of the respondents were as follows: $60.7 \%$ of them were males and $39.3 \%$ were females. Most of the respondents were between 25 to 34 years $(34.8 \%), 35$ to $44(31.3 \%)$ years of age and have university degree $(60.1 \%)$. More than half of participants were married (60.1\%) and had a monthly income of 1801 to 2700 TL (Turkish Lira) (31.6\%). Demographic characteristics of Respondents demonstrated in Table 2.

Table 2: Demographic Characteristics of Respondents

\begin{tabular}{|c|c|c|c|c|c|}
\hline & $\mathbf{n}$ & $\%$ & & $\mathbf{n}$ & $\%$ \\
\hline Gender & & & Age & & \\
\hline Males & 244 & 60.7 & $18-24$ & 82 & 20.4 \\
\hline \multirow[t]{2}{*}{ Females } & 158 & 39.3 & $25-34$ & 140 & 34.8 \\
\hline & & & $35-44$ & 126 & 31.3 \\
\hline Education & & & $45-54$ & 47 & 11.7 \\
\hline Grade School & 9 & 2.2 & 55 or above & 6 & 1.5 \\
\hline Secondary School & 23 & 5.7 & & & \\
\hline High School & 73 & 18.2 & & & \\
\hline University & 240 & 60.1 & Marital Status & & \\
\hline \multirow[t]{2}{*}{ Master/Doctorate } & 54 & 13.5 & Single & 144 & 35.9 \\
\hline & & & Married & 241 & 60.1 \\
\hline Monthly Income & & & Divorced/Separated & 16 & 3.9 \\
\hline $900 \mathrm{TL}$ and below & 24 & 7.2 & & & \\
\hline 901-1800 TL & 68 & 20.5 & & & \\
\hline $1801-2700 \mathrm{TL}$ & 105 & 31.6 & & & \\
\hline 2701-3600 TL & 85 & 25.6 & & & \\
\hline $3601-4500 \mathrm{TL}$ & 27 & 8.1 & & & \\
\hline $4500 \mathrm{TL}$ and above & 23 & 6.9 & & & \\
\hline
\end{tabular}

TL: Turkish Lira

Factor analysis was conducted in order to reduce variables prior to testing their reliabilities. Factor analysis results for alternative tourism types and lifestyle, and Cronbach's Alpha values of factors were demonstrated in Table 3 and Table 4. 
Table 3: Factor Analysis of Alternative Tourism Items

\begin{tabular}{|c|c|c|c|c|c|}
\hline Factors & $\begin{array}{l}\text { Factor } \\
\text { loading }\end{array}$ & $\begin{array}{l}\text { Eigen } \\
\text { value }\end{array}$ & $\begin{array}{l}\text { Variance } \\
\text { explained }\end{array}$ & Mean & Std. D. \\
\hline Nature and Sport Tourism $(\alpha=.79)$ & & 3.48 & $29.01 \%$ & 3.65 & .89 \\
\hline Water Sports & .73 & & & & \\
\hline Snow and Mountain Sports Tourism & .72 & & & & \\
\hline Mountaineering Tourism & .71 & & & & \\
\hline Outdoor Recreation & 67 & & & & \\
\hline Sports Tourism & .64 & & & & \\
\hline Adventure Tourism & .61 & & & & \\
\hline Hedonic Tourism $(\alpha=.60)$ & & 1.66 & $13.87 \%$ & 2.15 & 1.00 \\
\hline Gambling Tourism & .80 & & & & \\
\hline Wine Tourism & .78 & & & & \\
\hline Hunting, Fishing Tourism & .56 & & & & \\
\hline Intellectual Tourism $(\alpha=.63)$ & & 1.45 & $12.11 \%$ & 3.12 & .81 \\
\hline Congress Tourism & .78 & & & & \\
\hline Cultural Tourism & .78 & & & & \\
\hline Ecotourism & .64 & & & & \\
\hline Total Variance Explained & & & $55.01 \%$ & & \\
\hline
\end{tabular}

Note: KMO 0.77, Bartlett 1116.71, p<0.00, Cronbach's Alpha of Scale $\alpha=824$.

Alternative Tourism were evaluated using the scale of $1=$ strongly disagree, $2=$ disagree, $3=$ neither agree nor disagree, $4=$ agree, $5=$ strongly agree

Table 4: Factor Analysis of Lifestyle Items

\begin{tabular}{lccccc}
\hline Factors & $\begin{array}{c}\text { Factor } \\
\text { loading }\end{array}$ & Eigenvalue & $\begin{array}{c}\text { Variance } \\
\text { explained }\end{array}$ & Mean & $\begin{array}{c}\text { Std. } \\
\text { Deviation }\end{array}$ \\
\hline Experiencers $(\boldsymbol{\alpha}=. \mathbf{8 4})$ & & 4.74 & $26.36 \%$ & 3.69 & .87 \\
\hline I am always looking for a thrill & .83 & & & & \\
\hline $\begin{array}{l}\text { I like a lot of excitement in my } \\
\text { life }\end{array}$ & .83 & & & & \\
\hline I often crave excitement & .81 & & & & \\
\hline $\begin{array}{l}\text { I like doing things that are new } \\
\text { and different }\end{array}$ & .72 & & & & \\
\hline I like trying new things & .56 & & & & \\
\hline
\end{tabular}


Table 4 continued

\begin{tabular}{|c|c|c|c|c|c|}
\hline Strivers $(\alpha=.78)$ & & 2.29 & $12.74 \%$ & 3.00 & .97 \\
\hline $\begin{array}{l}\text { I want to be considered } \\
\text { fashionable }\end{array}$ & .79 & & & & \\
\hline $\begin{array}{l}\text { I like to dress in the latest } \\
\text { fashions }\end{array}$ & .79 & & & & \\
\hline $\begin{array}{l}\text { I dress more fashionably than } \\
\text { most people }\end{array}$ & .76 & & & & \\
\hline $\begin{array}{l}\text { I must admit that I like to show } \\
\text { off }\end{array}$ & .62 & & & & \\
\hline $\begin{array}{l}\text { I follow the latest trends and } \\
\text { fashions }\end{array}$ & .54 & & & & \\
\hline Believers $(\alpha=.60)$ & & 1.61 & $8.98 \%$ & 3.99 & .75 \\
\hline $\begin{array}{l}\text { The government should } \\
\text { encourage religious education } \\
\text { in schools }\end{array}$ & .75 & & & & \\
\hline $\begin{array}{l}\text { A woman's life is fulfilled only } \\
\text { if she can provide a happy } \\
\text { home for her family }\end{array}$ & .70 & & & & \\
\hline $\begin{array}{l}\text { I like my life to be pretty much } \\
\text { the same from week to week }\end{array}$ & .63 & & & & \\
\hline $\begin{array}{l}\text { There is too much sex on } \\
\text { television today }\end{array}$ & .52 & & & & \\
\hline Thinkers $(\alpha=.62)$ & & 1.28 & $7.13 \%$ & 4.02 & .85 \\
\hline $\begin{array}{l}\text { I like to learn about art, culture, } \\
\text { and history }\end{array}$ & .82 & & & & \\
\hline $\begin{array}{l}\text { I would like to understand more } \\
\text { about how the universe works }\end{array}$ & .76 & & & & \\
\hline \multicolumn{6}{|l|}{$\operatorname{Achievers}(\alpha=.70)$} \\
\hline I like to lead others & .84 & 1.08 & $6.02 \%$ & 3.65 & .99 \\
\hline I like being in charge of a group & .81 & & & & \\
\hline Total Variance Explained & & & $61.25 \%$ & & \\
\hline
\end{tabular}

Note: KMO 0.82, Bartlett 2254.71, p< 0.00, Cronbach's Alpha of Scale $\alpha=823$.

Lifestyle were evaluated using the scale of $1=$ strongly disagree, $2=$ disagree, $3=$ neither agree nor disagree,

4=agree, 5=strongly agree.

Lifestyle variables gathered under five factors, alternative tourism types variables gathered under tree factors. Kaiser-Meyer-Olkin statistics were 0.82 and 0.77 which indicated that the data were suitable for factor analysis. There were not any factor loadings below 0.50 , indicating a strong correlation between the items and the factor group they belong to. 
Cronbach's Alpha value over .70 is ideally reliable but over .60 is also acceptable (Hair et all, 1998).

In order to determine the relationship between lifestyle and demand for alternative tourism, multiple regression analysis was conducted. In order to determine the direction and strength of relationship between variables, correlation analysis was used. The results of multiple regression and correlation analysis were demonstrated in Table 5 and Table 6.

Table 5: Result of Multiple Regression Analysis

\begin{tabular}{lccccccc}
\hline & $\mathbf{t}$ & $\mathbf{p}$ & $\boldsymbol{\beta}$ & $\mathbf{F}$ & $\mathbf{d f}$ & $\mathbf{p}$ & $\mathbf{a d j .} \mathbf{R}^{\mathbf{2}}$ \\
\hline Overall Model & & & & 18.452 & 5 & .000 & .179 \\
\hline Experiencers & 6.131 & 000 & 323 & & & & \\
\hline Strivers & 1.254 & 211 & 064 & & & & \\
\hline Believers & -3.877 & 000 & .184 & & & & \\
\hline Achievers & 3.658 & 000 & 178 & & & \\
\hline Thinkers & -.262 & 793 & .013 & & & & \\
\hline
\end{tabular}

A significant regression equation was found $\left(\mathrm{F}(5,396)=18.452, \mathrm{p}<, 000, \mathrm{R}^{2}=189\right.$, $\left.\mathrm{R}_{\text {Adjusted }}^{2}=179\right)$. Experiencers, believers, and achievers were significant predictors of demand for alternative tourism. According to the results of multiple regressions analysis, lifestyle affects the demand for alternative tourism.

Table 6: Result of Correlation Analysis

\begin{tabular}{|c|c|c|c|c|}
\hline & $\begin{array}{c}\text { Alternative } \\
\text { Tourism }\end{array}$ & $\begin{array}{c}\text { Nature and } \\
\text { Sport Tourism }\end{array}$ & $\begin{array}{l}\text { Hedonic } \\
\text { Tourism } \\
\end{array}$ & $\begin{array}{c}\text { Intellectual } \\
\text { Tourism }\end{array}$ \\
\hline Experiencers & $.368^{* *}$ & $.415^{* *}$ & $.230^{* *}$ & $.148^{* *}$ \\
\hline Strivers & $.210^{* *}$ & $.193^{* *}$ & $.129^{* *}$ & $.136^{* * *}$ \\
\hline Believers & $-.108^{*}$ & .011 & $-.246^{* *}$ & .030 \\
\hline Achievers & $.218^{* * *}$ & $.252^{* * *}$ & -.043 & $.303^{* * *}$ \\
\hline Thinkers & $.125^{*}$ & $.128^{*}$ & .028 & $.126^{*}$ \\
\hline
\end{tabular}

**. Correlation is significant at the 0.01 level (2-tailed).

*. Correlation is significant at the 0.05 level (2-tailed).

There are significant relationships between 'experiencers, believers, achievers' and 'the demand for alternative tourism'. When the results of correlations analyses of these factors are examined, there are positive correlations between 'experiencers, achievers' and 'the demand for alternative tourism' at $\mathrm{p}<0.01$. There is a negative correlation between 'believers' and 'the demand for alternative tourism' at $\mathrm{p}<0.05$. Experiencers would like to try all kind of tourism types that are offered. Believers have a negative tendency to, i.e. they avoid, hedonic tourism. Achievers have a positive tendency to environment and culture. 


\section{Conclusion}

Tourism is an important industry especially for developing countries. Destinations which have tourist attractions compete fiercely in order to get more shares from this demand. Thus, destination marketing professionals focus on the question "why do tourists travel?". Based on answers of this question, more tourists could be attracted. Alternative tourism could be used as a tool to increase the attractiveness of a destination for tourists who have a higher awareness of the importance of environment, culture, nature, and history.

Alternative tourism may be considered both as an opportunity to protect tourism areas and a tool to diversify tourism products. Determining what affects the demand for alternative tourism could provide the opportunity to improve tourism marketing efforts.

Lifestyle is an important factor of customer decision making process and findings of this study reveals the effect of lifestyle on the demand for alternative tourism. People from same subculture may show different behavior in the market. As this study revealed, there are significant relationships between 'experiencers, believers, achievers' and 'the demand for alternative tourism'. These components of lifestyle have different primary motivation and sources. Each segment of lifestyle may demand different tourism products.

Experiencers have a positive tendency to all alternative tourism. So, they may be a target segment for all alternative tourism. It seems believers avoid consuming hedonic tourism products. Hence, religion tourism may be the best alternative tourism option if religionoriented customers constitute a significant proportion of the target market. Achievers have a positive tendency to nature and sport and intellectual tourism. So, the destinations which focus on these tourism types could create a more positive image in achievers' minds. Thus, destination marketing professionals should take tourist lifestyles into account in their market segmentation efforts and reach target markets with appropriate marketing tools. Therefore, destination marketing professionals may create different destinations which offer different tourism activities for different tourist types to get more shares from world tourism revenue.

Even though VALS II scale was developed to segment USA citizens, this scale was also used in different cultures (Wongsiriwat, 2007; Deniz et al., 2011; Yıldırım \& Cengel, 2013). This study revealed that the participants of this research could be segmented similarly with the US citizens. This could be the result of that globalization transforms the world into a small town.

\section{References}

Butler, R.W. (1990). Alternative tourism: Pious hope or trojan horse?. Journal of Travel Research, 28(3), 40-45.

Dale, M. (2010). BTEC level 3 national travel and tourism student book 1, Pearson Education Limited, Harlow, United Kingdom.

Deniz A., Godekmerdan, L., \& Yuce, A. (2011). A Study on determining the lifestyles of consumers who buy global branded products, Cumhuriyet University Journal of Economics and Administrative Sciences, 12(2), 79-90. 
Gartner, W. C. (1996). Tourism development: Principles, processes, and policies. New York: Van Nostrand Reinhold.

Hoyer, W. D., \& Maclnnis, D.J. (2008), Consumer behavior, 5th edition, South-Western, USA. Jersey.

Turkey in Statistics 2014 (2015). Turkish statistical institute, Ankara, Turkey.

Kaya, H. (2013). The effects of personal values on consumer's decision making styles: A study in Turkish Republic of Northern Cyprus, MBA Thesis, Cyprus International University.

Khan, M. (2006). Consumer behaviour and advertising management. New Age International Limited, Publishers 4835/24, Ansari Road, Daryaganj, New Delhi - 110002.

Kilıc, B., \& Kurnaz, A. (2010). Alternative tourism and ecological farms on creating diversification of tourism product: Example of pastoral valley, Isletme Arastırmalart Dergisi, 2(4), 39-56.

Kotler, P., \& Keller, K. L. (2012). Marketing management, 14th Edition, Prentice Hall Inc., New

Lertcharoenchoke, N. (1999). Alternative tourism, ABAC Journal, 19(2), 23-32.

Lin, F.Y. (2003). An analysis of hospitality consumer lifestyles in the United States, Texas Tech University, PhD Dissertation, USA, UMI.

Michman, R. D., Mazze, E. M., \& Greco, A. J. (2003). Lifestyle marketing: Reaching the new American consumer, Praeger Publishers, Westport.

Peter, J.P., \& Olson, J.C. (2010). Consumer behavior \& marketing strategy, 9th edition, New York: McGraw-Hill Irwin.

Smith, V., \& Eadington, W. (1992). Tourism alternatives: Potentials and problems in the development of tourism. University of Pennsylvania Press, Philadelphia.

Solomon, M., Bamossy, G., Askegaard, S., \& Hogg, M. K. (2006). Consumer behaviour: A European perspective, 3rd edition, Prentice Hall-Financial Times, Harlow.

Strategic Business Insights, (2015). VALS, http://www.strategicbusinessinsights.com/ vals/ ustypes.shtml, Date Accessed:15.02.2015.

Tezcan, B. (2004). Developing alternative modes of tourism in Turkey. Unpublished Dissertation, Middle East Technical University, Ankara.

UNWTO Tourism Highligths 2015 Edition (2015). World Tourism Organization UNWTO.

Wongsiriwat, K. (2006). A study of influences of values, attitudes and lifestyles (VALS II) on brand equity of luxury handbags in Bangkok, MBA Thesis, Shinawatra University.

Yildırım, F., \& Cengel, O. (2013). A research over the relationship between fast food consumption and consumer's values \& lifestyles in Turkey, Online Academic Journal of Information Technology, Winter, 4(11). 